\title{
The Portraits of Digital Literacy Awareness Amid Covid-19 Pandemic
}

\author{
Titis Angga Rini ${ }^{1,}$, Bagus Cahyanto ${ }^{2}$, Febrianita Putri Sholihah ${ }^{3}$ \\ ${ }^{1}$ Faculty of Education, Universitas Negeri Malang, Malang, Indonesia \\ ${ }^{2}$ Faculty of Islamic Education, Universitas Islam Malang, Malang, Indonesia \\ ${ }^{3}$ SDN Kepanjenlor 2, Blitar, Indonesia \\ ${ }^{*}$ Corresponding author. Email: angga.rini.fip@um.ac.id
}

\begin{abstract}
Digital literacy is a familiar topic in this millennial era with various digital media with open access that can be used anytime and anywhere. Based on this, this study aims to describe the digital literacy awareness of a family during the Covid-19 pandemic as a phenomenon that is currently being discussed. This study uses a type of phenomenology with data collection techniques through observation and interviews. The data extracted included knowledge assembly, utilization of digital sources and media, access and hypertextual navigation, content evaluation of the research subject, namely a family of various ages. The results showed that digital literacy awareness varied greatly from the media, access patterns, and evaluations carried out by each respondent in accessing information. It can be concluded that digital literacy awareness is still not optimal according to the indicators used and still needs to be improved, especially in building critical thinking patterns and utilizing technology as part of digital literacy.
\end{abstract}

Keywords: digital literacy, covid-19 pandemic, information access

\section{INTRODUCTION}

The digital era has brought big changes in various fields of life and has become a challenge for developing countries such as Indonesia. Various things that are currently packaged in digital form demand the readiness of the Indonesian people in utilizing and operating various tools for daily activities, one of which is awareness of the use of various informative media [1]. This challenge is supported by the results of the "Global Digital Reports 2020 " which shows that $64 \%$ of Indonesia's population is active internet users [2]. This phenomenon shows an increase every year (17\%) so that the digital process itself has taken root and the individual's awareness should be in their existence in accessing digital information [3].

Access to information is closely related to individual skills in digital literacy. Digital literacy has been popularized by Glister since 1997 as the ability to understand and use information from various sources displayed in computer format [4], [5]. In more detail, digital literacy skills are described as the ability to utilize various sources, operate various devices, and be able to determine the accuracy of access to information [6]. This ability will show the level of individual digital literacy awareness in accessing information and utilizing the media and its development.

Along with the development of digital media, news and issues are more easily accessible and made by anyone, anytime, anywhere. Especially during the Covid 19 pandemic, many issues arose from various digital media related to this information. Search results on search engines show that information about Covid-19 has always been in the headlines of news and has become one of the most sought-after and accessible topics for Indonesians. However, not all of the information reported is correct many hoaxes are deliberately spread by certain parties with various motives [7].

This phenomenon reaffirms the importance of digital literacy awareness from the community from an early age in accessing information. Following the results of research by Mohammadyari and Singh which states that digital literacy will facilitate individuals in using the internet and digital media [8]. The same thing was also expressed by Meyers et.al. also showed that digital literacy greatly implicates individual competence in following and mastering increasingly developing technology [9]. Based on this, researchers are interested in researching more deeply the digital literacy awareness of the Indonesian people through case studies. This study wants to answer "what is the level of digital literacy skills and awareness of a family in their daily lives when accessing digital information related to the topic of Covid-19".

\section{METHOD}

This study uses a short phenomenology to explore the phenomena that a group of individuals experiences as their life experiences. The research was conducted from 22 May 2020 to 15 June 2020 through observation and interviews. The research was carried out by: (a) 
determining the procedure and research focus, (b) literature review, (c) problem formulation, (d) data collection, (e) processing and analysis, (f) concluding. The research subjects were six members of a family of various ages and educational backgrounds (Table 1). The phenomenon studied is about how the level of awareness and digital literacy skills of each family member were selected during the Covid-19 pandemic with the consideration of age differences and educational background of each member. The study was limited to one month by considering the adequacy of time for extracting data.

Table 1 Research Subjects

\begin{tabular}{|l|c|l|}
\hline Code & \multicolumn{2}{|c|}{ Age and Background } \\
\hline R09 & 09 yo & Student at 3rd elementary school \\
\hline R11 & 11 yo & Student at 6th elementary school \\
\hline R22 & 22 yo & Final year college student \\
\hline R45 & 45 yo & Housewife, last education: senior high school \\
\hline R46 & 46 yo & Housewife, last education: senior high school \\
\hline R48 & 48 yo & $\begin{array}{l}\text { Entrepreneur, last education: senior high } \\
\text { school }\end{array}$ \\
\hline
\end{tabular}

The data was extracted using observation, interviews, and in-depth documentation of each source. Data were collected using field notes for observation (Ob1, Ob2, $\mathrm{Ob} 3$, and $\mathrm{Ob} 4$ ) and an interview guide that includes four indicators, referring to the digital literacy component of Gilster [10]. First knowledge assembly, describes the ability to compile and construct information obtained from various sources. Second, the utilization of digital sources and media describes the ability to use digital sources and media in accessing information. Third access and hypertextual navigation describe the ability to navigate and operate digital media and sources. Fourth content evaluation describes the ability to analyze and assess the accuracy of digital information.

The data from this study were then tested for their validity through technical triangulation on each research subject. The data were analyzed using qualitative descriptive techniques referring to the analysis technique of Milles and Huberman (1984) through data collection, reduction, presentation, and conclusion drawing. The final section of this study will generalize the cases investigated by conducting theoretical and empirical studies discussing the level of awareness and literacy abilities of research subjects.

\section{RESULT \& DISCUSSION}

Under the limitations of the research as the case under study, the portrait of digital literacy awareness of a family will be described in four assessment indicators, the first is the accuracy of information. Accuracy of information describes the accuracy of information received and interpreted by respondents about the topics raised in this study, namely, the Covid-19 Pandemic. The following are the results of extracting the data.

\subsection{Knowledge Assembly}

The first indicator shows the information the respondent gets about the topic raised. All respondents indicated the same keyword that Covid-19 is a contagious disease, but with a different understanding from the explanation given. The majority of respondents did not update the information with the latest issues, only two respondents stated the latest relevant information from the topic. This shows that the accuracy of information received by respondents is mixed between correct and incorrect information. This indicator shows the acquisition of critical thinking knowledge is needed in various information contexts [11], [12]. The following is direct information from the respondents.

"...A virus that makes us sick, can be contagious and causes death..." (W/R09/01).

"...A virus that spreads around the world and attacks the human immune system...” (W/R46/01).

From all the information obtained from the information obtained, it is also observed the behavior shown. The data extracted shows that the information obtained is trying to be applied in everyday life such as suggestions for maintaining health and others (Ob1/10/05). This data shows that the existence of a topic has a major influence on the access made by respondents [13]. In particular, topics that are considered to have a direct impact, on this topic are about health, in daily life. Curiosity is the main motivation in accessing this information [14], [15]. The following is direct information from the respondents.

"...I just want to know, to increase knowledge, because it is important to take care of oneself..." (W/R46/02).

"... Often until now, want to know the true incident with searching the information...” (W/R22/02).

\subsection{Utilization of Digital Sources and Media}

The majority of information obtained by respondents was accessed online via search engines and social media (R11, R22, R45, R46), while others explained that more information was obtained from television shows (R09, R48). This information is accessed intentionally or unintentionally in connection with the topics raised, especially the top stories in its search. The following is direct information from the respondents.

"...I accidentally read, I purposely searched for the keyword Covid-19, then choose the top news..." (W/R11/02).

It is known that each respondent in this family has a smartphone with their data access. The words google, Facebook, YouTube is mostly used by respondents in explaining the media to access information $(\mathrm{Ob} / 21 / 06)$. This shows that digital family activities follow the trend 
of Indonesian people who tend to use the media. This suggests a deep invasion of the use of digital media as an interconnected public space [16], [17]. This 21st-century society can easily use a variety of digital media because of its openness and unlimited access to space and time [18].

\subsection{Access and Hypertextual Navigation}

Access to information by respondents regarding the topics raised in this study tends to be inconsistent. All respondents stated that at the beginning of the emergence of the topic of a pandemic, access to information was done as often as possible to find out the latest information. On the other hand, nowadays access to information on the topic is reduced or even not carried out, because the topic has become a general phenomenon.

Respondents recognized the importance of access to information regarding the topic in this study, but access to other information was also carried out. Based on observations, other information is only accessed at a glance, such as issues of education, economic development, and others. Such information tends to be accidentally accessed and only accessed at the moment without any further information extraction or validation. The indicators of information attractiveness are consistent keywords that emerge from respondents when data is collected about their purpose for accessing information. The following is direct information from the respondents.

“...Important, I'm curious so I want to read it" (R46).

"If there is another news about education, the problem is school children, right now online learning..." (W/R45/03).

"Usually the ones for assignment or accidentally appear and I am interested, then only read briefly..." (W/R22/03).

The questions from these respondents indicated that they were aware of accessing news through various media to update the information they had with their respective objectives and indicators. When the question was related to the term "literacy", the majority of respondents stated that they did not know the term. Only one respondent stated that literacy is important but with an inaccurate definition. The following is direct information from the respondents.

"...Yes, literacy is data collection about the data collection of someone's opinions, knowing from people is why literacy is important..." (W/R46/03)

At the time of extracting data, several respondents were asked to practice how to search for information with the media. R09 shows good proficiency in using youtube by entering keywords via voice access. R11 and R22 shows good proficiency in using a variety of social media, software, and hypertext such as links, download managers, web meetings, video and photos editing, and others, especially to complete school assignments. R11 can explain well the function of each media used, for example, to view videos, YouTube is used, to see the personal status, Instagram is used, while browsers like Google are used to search for information. Meanwhile, R45 and R46 are limited to only using google (respondents do not understand the term browser) deliberately entering keywords and through Facebook, they accidentally read the top viral news. On the R48 there is no use of the internet, information tends to be accessed through the news on television directly. R48 states that it has limited ability to operate the internet and other devices.

From the results of this study, it can be observed that different patterns of access to information are based on the age of the respondents. Generation $\mathrm{Y}$ and $\mathrm{Z}$ respondents are more skilled and dependent on digital media, whereas generation $\mathrm{X}$ and baby boomers tend to still use old ways or habits in accessing information [19]. This explains the gap between millennials and previous generations, millennials are believed to have a pre-digital foundation starting from content that is close to technological developments [20].

\subsection{Content Evaluation}

Furthermore, data were extracted on the confirmation process of the information obtained by the sources. Respondents stated that they were not completely sure of the existing news, they believed there were hoaxes, to opinions about the use of news for certain interests for some media. According to respondents, they will do news validation by viewing live broadcasts or reading news portals from the Indonesian government's Ministry of Health which are routinely served every day, or by comparing facts in the environment from the experiences and information of others which they think can be trusted as follows.

“...Of course not, because all media raise news based on their respective interests..." (W/R22/04).

"...I see, hear, and investigate by matching the facts" from the surrounding environment...” (W/R46/04)

"...Seeing based on evidence the Ministry of Health, just believe..." (W/R22/04)

"...Because in my village there were positive ones but the protocol is normal, this is my judgment..." (W/R45/04).

The information obtained is interpreted by each respondent and then produces arguments in private or outlined in the form of comments or status that are shared with the general public. The following is direct information from the respondents.

“...I've only ever participated in comments on social media about events refusal of the bodies of nurses who are positive for Covid-19..." (W/R46/04)

"... Once, there was news that strong winds brought the coronavirus and remind corona vigilance..." (W/R45/04) 
Furthermore, R45 stated that the information shared was obtained from colleagues who are health workers who are members of the parent group of their children. In this group, parents often discuss developments related to their children's activities for school (Ob1/22/05). In R46 it was observed that respondents were very active in using social media, Facebook, to interact with their colleagues and other users who did not know each other by commenting on posts that were considered viral.

Meanwhile, respondents are not very active in using social media. R48 tends to get the news when discussing and chatting with colleagues. Activeness is of course very dependent on the ability to use media, according to the research results of Park and Nam (2014) that age has quite an influence on the use of digital media [21]. Although this influence can vary at different ages in digital literacy [22]. This demonstrates the importance of developing pedagogical strategies in building digital literacy skills in stages by age [23].

In this situation, it can be observed that R48 tends to believe the information it gets and then passes it on to other family members $(\mathrm{Ob} 1 / 01 / 06)$. When receiving this information, R22 showed the news from the official government website so that a comparison and clarification process took place on the accuracy of the information. This pattern is repeated for $\mathrm{R} 45, \mathrm{R} 46$, and $\mathrm{R} 48(\mathrm{Ob} / 02-$ 10-21 / 06). From this indicator, it can be concluded that the digital literacy level of the community still needs to be improved. This fact becomes a challenge to foster critical responses in various contexts where it takes more than just technical skills [11] but also needed to utilize the media [24], [25].

\section{CONCLUSION}

The conclusions obtained from the results of this study indicate that the level of digital literacy awareness varied from each respondent of different ages during the Covid-19 pandemic. Digital literacy awareness is shown by the use of various media, access patterns, and evaluations by respondents towards the information they receive.

Various digital media are used to access various information, especially for younger respondents. It can be concluded that the portrait of digital literacy awareness has not yet appeared optimally because access to information is still dominated by trending topics or hot issues circulating in the community. Access to information is not carried out continuously on other topics outside of trending topics such as the Covid-19 pandemic. The amount of hoax information that is still considered true without any evaluation shows that the critical thinking of each respondent still needs to be improved.

\section{REFERENCES}

[1] T. Koltay, "New media and literacies: Amateurs vs. professionals," FM, Dec. 2010, doi: 10.5210/fm.v16i1.3206.
[2] N. S. Mudawamah, "Perilaku Pengguna Internet: Studi Kasus Pada Mahasiswa Jurusan Perpustakaan Dan Ilmu Informasi Uin Maulana Malik Ibrahim.," Bibliotika: Jurnal Kajian Perpustakaan Dan Informasi, vol. 4, no. 1, pp. 107 113, 2020.

[3] R. Sharma, A.-R. Fantin, N. Prabhu, C. Guan, and A. Dattakumar, "Digital literacy and knowledge societies: A grounded theory investigation of sustainable development," Telecommunications Policy, vol. 40, no. 7, pp. 628-643, Jul. 2016, doi: 10.1016/j.telpol.2016.05.003.

[4] Q. Abbas, S. Hussain, and S. Rasool, "Digital Literacy Effect on the Academic Performance of Students at Higher Education Level in Pakistan," GSSR, vol. IV, no. I, pp. 108-116, Mar. 2019, doi: 10.31703/gssr.2019(IV-I).14.

[5] S. C. Ukwoma, N. E. Iwundu, and I. E. Iwundu, "Digital literacy skills possessed by students of UNN, implications for effective learning and performance: A study of the MTN Universities Connect Library," New Library World, vol. 117 , no. $11 / 12$, pp. 702-720, Nov. 2016, doi: 10.1108/NLW-08-2016-0061.

[6] I. Mariën, D. Baelden, and C. Iordache, "Developing Digital Skills and Competences: A Quick-Scan Analysis of 13 Digital Literacy Models," Italian Journal of Sociology of Education, vol. 9, no. 02/2017, pp. 6-30, 2017, doi: 10.14658/pupj-ijse-2017-1-2.

[7] I. Bafadal, A. Nurabadi, A. Y. Sobri, and I. Gunawan, "The Competence of Beginner Principals as Instructional Leaders in Primary Schools," Int. J. Innov. Creat. Chang, vol. 5, no. 4, pp. 625-639, Aug. 2020.

[8] S. Mohammadyari and H. Singh, "Understanding the effect of e-learning on individual performance: The role of digital literacy," Computers \& Education, vol. 82, pp. 1125, Mar. 2015, doi: 10.1016/j.compedu.2014.10.025.

[9] E. M. Meyers, I. Erickson, and R. V. Small, "Digital literacy and informal learning environments: an introduction," Learning, Media and Technology, vol. 38, no. 4, pp. 355-367, Dec. 2013, doi: 10.1080/17439884.2013.783597.

[10] R. H. Jones and C. A. Hafner, Understanding digital literacies: A practical introduction. New York City, NY, USA: Routledge, 2012.

[11] L. Pangrazio, "Reconceptualising critical digital literacy," Discourse: Studies in the Cultural Politics of Education, vol. 37, no. 2, pp. 163-174, Mar. 2016, doi: 10.1080/01596306.2014.942836.

[12] S. C. Kong, "Developing information literacy and critical thinking skills through domain knowledge learning in digital classrooms: An experience of practicing flipped classroom strategy," Computers \& Education, vol. 78, pp. 160-173, Sep. 2014, doi: 10.1016/j.compedu.2014.05.009.

[13] K.-L. Nguyen, Byung-Joo Shin, and Seong Joon Yoo, "Hot topic detection and technology trend tracking for patents utilizing term frequency and proportional document frequency and semantic information," in 2016 International Conference on Big Data and Smart Computing (BigComp), Hong Kong, China, Jan. 2016, pp. 223-230, doi: 10.1109/BIGCOMP.2016.7425917.

[14] K. Rajaraman and A.-H. Tan, "Topic Detection, Tracking, and Trend Analysis Using Self-Organizing Neural 
Networks," in Advances in Knowledge Discovery and Data Mining, vol. 2035, D. Cheung, G. J. Williams, and Q. Li, Eds. Berlin, Heidelberg: Springer Berlin Heidelberg, 2001, pp. 102-107.

[15] M. Khosrow-Pour, D.B.A., Ed., Encyclopedia of Information Science and Technology, Fourth Edition: IGI Global, 2018.

[16] A. A. Abdel-Aziz, H. Abdel-Salam, and Z. El-Sayad, "The role of ICTs in creating the new social public place of the digital era," Alexandria Engineering Journal, vol. 55, no. 1, pp. 487-493, Mar. 2016, doi: 10.1016/j.aej.2015.12.019.

[17] J. Meneses and J. M. Mominó, "Putting Digital Literacy in Practice: How Schools Contribute to Digital Inclusion in the Network Society," The Information Society, vol. 26, no. 3, pp. 197-208, Apr. 2010, doi: 10.1080/01972241003712231.

[18] W. Ng, "Can we teach digital natives digital literacy?," Computers \& Education, vol. 59, no. 3, pp. 1065-1078, Nov. 2012, doi: 10.1016/j.compedu.2012.04.016.

[19] L. Leung, "Generational differences in content generation in social media: The roles of the gratifications sought and of narcissism," Computers in Human Behavior, vol. 29, no. 3, pp. 997-1006, May 2013, doi: 10.1016/j.chb.2012.12.028.

[20] S. R. Madara, P. Maheshwari, and C. P. Selvan, "Future of millennial generations: A review," in 2018 Advances in
Science and Engineering Technology International Conferences (ASET), Abu Dhabi, Feb. 2018, pp. 1-4, doi: 10.1109/ICASET.2018.8376927.

[21] E.-Y. Park and S.-J. Nam, "An analysis of the digital literacy of people with disabilities in Korea: verification of a moderating effect of gender, education and age: The digital literacy of people with disabilities," International Journal of Consumer Studies, vol. 38, no. 4, pp. 404-411, Jul. 2014, doi: 10.1111/ijcs.12107.

[22] K.-Y. Jin, F. Reichert, L. P. Cagasan, J. de la Torre, and N. Law, "Measuring digital literacy across three age cohorts: Exploring test dimensionality and performance differences," Computers \& Education, vol. 157, p. 103968 , Nov. 2020, doi: 10.1016/j.compedu.2020.103968.

[23] A. Antonio and D. Tuffley, "Bridging the Age-based Digital Divide:," International Journal of Digital Literacy and Digital Competence, vol. 6, no. 3, pp. 1-15, Jul. 2015, doi: 10.4018/IJDLDC.2015070101.

[24] Y. E. Alkali and Y. Amichai-Hamburger, "Experiments in Digital Literacy," CyberPsychology \& Behavior, vol. 7, no. 4, pp. 421-429, Aug. 2004, doi: $10.1089 /$ cpb.2004.7.421

[25] B. A. Buchholz, J. DeHart, and G. Moorman, "Digital Citizenship During a Global Pandemic: Moving Beyond Digital Literacy," J Adolesc Adult Liter, vol. 64, no. 1, pp. 11-17, Jul. 2020, doi: 10.1002/jaal.1076. 